четаются образы и категории политической жизни Руси-Украины, Речи Посполитой, Войска Запорожского и Московского ичарства. Проявляя лояльность к монарху, как образу высшей власти, проповедник склоняется к идеям республиканизма.

Ключевые слова: украинская философия, философия права, политическая философия, барокко, идентичность, самовластие, республиканизм.

Spivak V. V.

\title{
POLITICAL AND LEGAL CATEGORIES AS A MARKER OF IDENTITY IN THE HERITAGE OF ANTHONII RADYVYLOVSKYI
}

In clause the problem of political identity of Antoniy Radivilovskiy- the Ukrainian preacher and the church thinker of second half XVII century is investigated. The general intellectual background creative thinker and the place of his achievements in the spiritual tradition of the Baroque. Characterized by ideological foundation of his work and defined philosophical problems which drew attention thinker in his sermons. It is concluded that the presence of his homiletic heritage significant philosophical and legal and philosophical and political aspect that makes these works quite promising source for studying the history of Ukrainian philosophy. On the basis of the analysis of moral - ethical, philosophy-political and philosophy-legal components his hand-written and printed sermon heritages, come to light political and legal ideological preferencesof Antoniy Radivilovskiy and political order with which he identifies himself. It is judged about eclecticism of his political outlook in which images and categories of a political life of Russia-Ukraine, Rzeczpospolita, Zaporozhian Host and Moscow are combined. It is established, that showing demonstrative loyalty to the Moscow monarch as to an image of the higher authority, the preacher is declined to ideas of republicanism, characteristic for political way of Rzeczpospolita. The study complements our understanding of the ideological arsenal of political and legal philosophy thinkers Ukrainian Baroque.

Key words: the Ukrainian philosophy, philosophy of law, political philosophy, a baroque, identity, autocracy, republicanism.

УДК 341.492 .2

Гринчак А. А., доцент кафедри державного будівництва,

Національний юридичний університет імені Ярослава Мудрого, м. Харків

\section{ОЗНАКИ ЗЛОЧИНІВ ПРОТИ ЛЮДЯНОСТІ ЗА СТАТУТОМ МІЖНАРОДНОГО КРИМІНАЛЬНОГО ТРИБУНАЛУ ПО КОЛИШНІЙ ЮГОСЛАВІЇ}

Статтю присвячено аналізу ознак злочинів проти людяності за статутом Міжнародного кримінального трибуналу по колитній Югославї та його практики щуодо циих злочинів. Розкрито визначення злочинів проти людяності як таких, щуо 
вчиняються «у ході збройного конфлікту, міжнародного чи внутрішнього характеру, і спрямовані проти будь-якого ичивільного населення». Особливу увагу приділено характерним ознакам злочинів проти людяності, а саме: спрямованості проти ичивільного населення, організованості і систематичності, масштабності дій.

Ключові слова: злочини проти людяності, Міжнародний кримінальний трибунал по колишній Югославї.

Постановка проблеми. Термін «злочини проти людяності» був уперше вжитий після II світової війни. Були створені міжнародні воєнні трибунали ad hoc у Нюрнбергу i Токіо, які судили головних воєнних злочинців за злочини проти людства (у Статутах цих трибуналів були зазначені і злочини проти людяності) [1]. Це був прецедент у міжнародному праві. Він дав поштовх розвитку усьому післявоєнному міжнародному праву.

Наступним етапом розвитку концепції злочинів проти людяності було створення двох міжнародних трибуналів ad hoc: Міжнародного кримінального трибуналу для судового переслідування осіб, відповідальних за серйозні порушення міжнародного гуманітарного права, вчинені на території колишньої Югославії 3 1991 р. (далі МКТЮ) [2], і Міжнародного кримінального трибуналу для судового переслідування осіб, відповідальних за геноцид і інші серйозні порушення міжнародного гуманітарного права, вчинені на території Руанди, і громадян, відповідальних за геноцид чи подібні порушення, вчинені на території сусідніх держав, у період 31 січня до 31 грудня 1994 р. [3].

Аналіз практики Судової та Апеляційної палат МКТЮ щодо злочинів проти людяності (одного з видів злочинів, передбачених його Статутом) є метою цієї статті. Актуальність цього дослідження беззаперечно підкреслює той факт, що цього року трибунал завершує свою роботу. Для підбиття підсумків 24-річної діяльності МКТЮ 22-24 червня в Сараєво проведено заключну конференцію, де місцеві, регіональні та міжнародні учасники обговорювали різні аспекти правової спадщини МКТЮ, щоб навіть після завершення роботи трибуналу забезпечити доступ до інформацї̈ про досягнення і напрацювання МКТЮ для зацікавлених сторін [4].

Метою статті $є$ визначення ознак злочинів проти людяності за статутом Міжнародного кримінального трибуналу по колишній Югославї. 
Аналіз останніх досліджень і публікацій. Питання злочинів проти людяності завжди викликало інтерес як у вітчизняних, так і в зарубіжних дослідників (Бассіуні Ш. М., Бліщенко І. П., Гнатовський М. М., Грефрат Б., Зелінська Н. А., Морріс В., Рабінович П. М. та інші). Втім, окремі аспекти діяльності МКТЮ, зокрема, судова практика щодо злочинів проти людяності, недостатньо висвітлені в науковій літературі.

Виклад основного матеріалу. Трибунал став першим Міжнародним кримінальним трибуналом, створеним за резолюцією ООН. Його єдиними попередниками були міжнародні воєнні трибунали в Нюрнбергу і Токіо, створені за інших обставин та грунтувалися на фундаментально відмінних моральних і правових засадах [5].

Завданнями трибуналу є здійснення правосуддя, запобігання вчиненню певних злочинів і сприяння відновленню і підтримуванню миру. Заснування МКТЮ стало правовою відповіддю світової спільноти на вимоги, поставлені ситуацією у колишній Югославії, де у величезних масштабах вчинялися воєнні злочини, геноцид і злочини проти людяності: для засудження винних за ці категорії злочинів був створений цей трибунал.

На той час як уже існувало новітне інституціональне явище в міжнародно-правовій сфері, то трибунал спочатку (у 1994 р.) стикався 3 деякими практичними невизначеностями і критикою щодо його правової обгрунтованості й ефективності. Але подальша практика трибуналу спростувала ці сумніви.

За Статутом МКТЮ здійснює юрисдикцію щодо воєнних злочинів (ст. 2 і 3), геноциду (ст. 4) і злочинів проти людяності (ст. 5).

Характерною рисою Статуту є відокремлення геноциду від злочинів проти людяності (на відміну від Нюрнберзького і Токійського трибуналів). Як злочини проти людяності у ст. 5 Статуту Югославського трибуналу вказані вбивства, винищення, поневолення, депортація, ув'язнення, тортури, згвалтування, переслідування 3 політичних, расових чи релігійних мотивів, інші нелюдські акти [2].

У статті 5 Статуту МКТЮ визначаються злочини проти людяності як такі, що вчиняються «у ході збройного конфлікту, міжнародного чи внутрішнього характеру, і спрямовані проти будь-якого цивільного населення» [2]. 
У Статуті не подається тлумачення ознак злочинів, про які йдеться у статті. Судова й Апеляційна палати Трибуналу у разі застосування положень Статуту розкривали їх зміст, сформувавши значну судову практику [6].

Судова практика трибуналу виокремлює три ознаки злочинів проти людяності: а) спрямованість проти цивільного населення, б) організованість і систематичність, в) масштабність дій [7, п. 543]. У той же час рішення МКТЮ закріплюють положення, що друга і третя ознаки можуть бути альтернативними. Тобто достатньо, щоб акти вчинялися організовано й систематично (винний вчинив два і більше тотожні злочини як вияв певної тенденції його поведінки відповідно до заздалегідь розробленого плану чи політики) або масштабно, інакше кажучи, у великих розмірах [8, п. 544]. Організованість, систематичність i/або масштабність свідчать про колективний характер злочинів. Слід пам'ятати, що хоча концепція злочинів проти людяності припускає елемент політики, це не є обов'язковою ознакою злочинів проти людяності. У будь-якому випадку така політика необов'язково повинна визначатись державою [8, п. 551-555].

Об'єктом нападу в разі вчинення злочинів проти людяності $є$ саме цивільне населення. Використання терміна «населення» визначає колективну природу злочинів і виключає одиничні або ізольовані дії, які хоча і можуть являти собою військові злочини чи злочини за національним кримінальним законодавством, але не досягають рівня злочинів проти людяності. Ті особи, які брали активну участь у конфлікті, не можуть характеризуватися як цивільне населення, а ті, хто активно брав участь у русі опору, можуть кваліфікуватися як жертви злочинів проти людяності.

Сторони конфлікту мають усвідомлювати різницю між цивільним населенням і комбатантами, між цивільними і військовими цілями, i, відповідно, спрямовувати свої дії тільки проти військових цілей [9, п. 190]. У міжнародному праві існує абсолютна заборона нападу на цивільне населення [10, п. 109], що охоплює i напади невибіркового характеру. Не можуть конкретні райони або зони бути визначені як цивільні або військові. Різниця має бути проведена в кожному випадку між цивільним населенням і комбатантами, а також між цивільними і військовими цілями. Не можна 
виправдовувати напад на цивільне населення тим, що навколо розташовано багато військових об'єктів.

Масштабність i/або систематичність нападу на цивільне населення $є$ визначальною для дій окремого обвинуваченого і для нападу в цілому. Дії обвинуваченого як частина нападу на цивільне населення не обов'язково повинні відбуватися під час нападу (тобто дії, які вчиняються до або після основного нападу на цивільне населення або далеко від нього теж можуть бути частиною цієї атаки) [11, п. 100].

Доведення вини обвинуваченого у вчиненні злочинів проти людяності можливе за умови, що він усвідомлював зв'язок його дій 3 нападом [10, п. 101; 11, п. 99, 102, 103; 12, п. 248, 251, 271]. Така оцінка проводиться індивідуально щодо кожного випадку. Наприклад, розглянувши обставини, за яких діяння було вчинене так далеко від нападу, що не можна встановити необхідний зв'язок, вважається, що це так званий «ізольований акт», i, отже, він не може кваліфікуватися як злочин проти людяності [10, п. 101; 11, п. 100].

Злочини проти людяності повинні вчинятися під час збройного конфлікту і бути спрямовані проти будь-якого цивільного населення. Це означає, що повинен існувати збройний конфлікт, а всі акти мають бути пов'язані з конфліктом географічно і вчиняються не за особистими мотивами злочинця.

Все, що вимагається згідно зі статтею 5 Статуту, це те, щоб масштабний або систематичний напад на цивільне населення був проведений під час збройного конфлікту в Хорватії та/або Боснії і Герцеговині [13, п. 14].

Стала судова практика підтвердила, що існування збройного конфлікту не є складовою визначення злочинів проти людяності, але $\epsilon$ юрисдикційною умовою - дії обвинувачених географічно $\mathrm{i}$ в часі пов'язані зі збройним конфліктом; в іншому випадку не підпадають під юрисдикцію цього трибуналу $[11$, п. 82, 83; 12 , п. 249, 251; 14, п. 70].

Далі необхідно звернути увагу на особливі ознаки винищення як одного з найчисленіших злочинів проти людяності у судовій практиці МКТЮ.

Для винищення вина обвинуваченого доведена, якщо встановлено намір вбивати у великих масштабах або систематично ство- 
рювати великій кількості людей умови життя, які призвели б до їх смерті $[15$, п. 536; 16, п. 259, 260; 17, п. 45]. Ознаки злочину винищення $є$ такими ж, як ті, які потрібні для вбивства як злочину проти людяності, з тією різницею, що під час винищення вчиняються вбивства у великих масштабах [15, п. 536; 16, п. 260; 18, п. 701; 19, п. 261]. Вчинення у великих масштабах є одночасно необхідною характеристикою як об'єктивної сторони, так і суб'єктивної (намір і бажання вбити велику кількість людей) [15, п. 536; 16, п. 259; 17, п. 44; 20, п. 146]. Саме ця ознака - «широкомасштабність» (massiveness) - відрізняє злочин винищення від злочину вбивства $[15$, п. 536; 16, п. 260; 20, п. 146]. Однак вислів «у великих масштабах» не передбачає необхідність чіткого визначення мінімальної кількості жертв, після чого дії точно можна кваліфікувати як винищення [15, п. 537; 16, п. 260]. Винищення буде й у випадку вбивств тисяч осіб, і так само з меншою кількістю вбивств [15, п. 537]. Оцінка «великих масштабів» проводиться на індивідуальній основі, з урахуванням обставин, за яких відбувалися вбивства $[15$, п. 538; 21, п. 63; 22, п. 640; 23, п. 391; 24, п. 57; 25, п. 716]. Також Апеляційна палата визначила, що мають бути встановлені ще й такі фактори: а) час і місце вбивства, б) вибір жертв і порядку, в якому вони були спрямовані $[15$, п. 538]; в) тип жертв [15, п. 542]; г) націленість вбивств на колективну групу чи на індивідуальні жертви [15, п. 538] і д) щільність населення на території, звідки походять жертви [15, п. 539, 542, 543], але не виключається існування й інших. Ці фактори не є ознаками злочину винищення як злочину проти людяності, а швидше $є$ обставинами, які беруться до уваги і допомагають суду під час встановлення ознаки «широкомасштабність» $[15$, п. 542]. Окремі вбивства можуть бути частиною однієї і тієї ж операції [20, п. 147]. У такому випадку повинні враховуватися обставини, в яких вони відбувалися [20, п. 149]. Декілька вбивств, скоєних у різних місцях, у різних обставинах, різними злочинцями протягом тривалого періоду часу, не можуть розглядатися як злочини, вчинені у великих масштабах. У той же час суд може взяти до уваги часові рамки під час оцінки вбивств - чи $є$ вони частиною однієї і тієї ж операції [26, п. 1022].

Закон не встановлює чітких термінів, протягом яких повинно бути вчинено винищення [20, п. 147]. Вказані часові рамки беруться 
до уваги в сукупності з іншими обставинами під час визначення, чи є вбивства частиною однієї операції [20, п. 147; 26, п. 1022].

Висновки. Підбиваючи підсумки роботи МКТЮ, можна навести таку статистику: 154 обвинувачених, розгляд справ щодо яких завершено; 37 справ припинені (або через зняття обвинувальних висновків, або через те, що обвинувачений помер до або після передачі в Трибунал); тривають слухання у 2 справах щодо 7 обвинувачених (у Судовій палаті - розгляд справи щодо Златко Младича, а в Апеляційній палаті - справи Ядранка Прлича і ще 5 обвинувачених заплановано на листопад 2017); 28 осіб стали суб’єктами процедури розгляду так званих «contempt cases» [27].

Треба підкреслити, безумовно, значний вплив діяльності МКТЮ на розвиток міжнародного гуманітарного і кримінального права та міжнародної кримінальної юстиції. Практика суду заповнила правові прогалини щодо окремих міжнародних злочинів і злочинів проти людяності, зокрема, і стала вагомим чинником під час розробки статуту Міжнародного кримінального суду, спеціального суду по Сьєрра-Леоне та інших судових установ. Діяльність МКТЮ довела, що міжнародна кримінальна юстиція $\epsilon$ ефективною і прозорою. А визначення злочинів проти людяності розкривається в наступних міжнародних документах, 3 урахуванням усіх надбань і досягнень МКТЮ.

\section{Список використаних джерел}

1. У Проекті кодексу проти миру і безпеки людства Комісія міжнародного права ООН чітко розрізняє термін «людство» (mankind) i «людяність» (humanity), а злочини проти людяності визнає одним з видів злочинів проти людства // Проект кодексу злочинів проти миру і безпеки людства. URL: http://legal.un.org/docs/?path=/ilc/texts/instruments/english/ draft_articles/7 4 1996.pdf\&lang=EF.

2. Статут Міжнародного кримінального трибуналу для колишньої Югославії (доповнений). URL: http://www.icty.org/x/file/Legal Library/Statute/statute_sept09_en.pdf.

3. Статут Международного трибунала по Руанде (1994) // Моск. журн. междунар. права. 1996. № 1. С. 227-238.

4. Трибунал звинуватив загалом 161 людину і вже завершив розгляд відносно 154 з них ... // About MICT. URL: http://www.unmict.org/en/about. 
5. Маєвська А. А. Злочини проти людяності: міжнародно-правовий аспект: дис. ... канд. юрид. наук. Харків, 2002. С. 14-27.

6. Каталог справ МКТЮ. URL: http://www.icty.org/en/action/cases/4.

7. Objective and Subjective Elements of the Crimes Under Article 5. URL: http://www.icty.org/x/cases/kupreskic/tjug/en/kup-tj000114e-5.htm.

8. Kupreskic Trial Judgement. URL: http://www.icty.org/x/cases/ kupreskic/tjug/en/kup-tj000114e-5.htm.

9. Galić Appeal Judgement. URL: http://www.icty.org/x/cases/galic/ acjug/en/gal-acjud061130.pdf.

10. Blaškić Appeal Judgement. URL: http://www.icty.org/x/cases/ blaskic/acjug/en/bla-aj040729e.pdf.

11. Kunarac et al. Appeal Judgement. URL: http://www.icty.org/x/cases/kunarac/acjug/en/kun-aj020612e.pdf.

12. Prosecutor v. Duško Tadić, Case No. IT-94-1-A, Judgement, 15 July 1999 («Tadić Appeal Judgement»). URL: http://www.icty.org/x/cases/ tadic/acjug/en/tad-aj990715e.pdf.

13. Decision on the Interlocutory Appeal Concerning Jurisdiction, 31 August 2004. URL: http://www.icty.org/x/cases/seselj/acdec/en/040831.htm.

14. Decision on the Defence Motion for Interlocutory Appeal on Jurisdiction, 2 October 1995. URL: http://www.icty.org/x/cases/tadic/ acdec/en/51002.htm.

15. Lukić and Lukić Appeal Judgement. URL: http://www.icty.org/x/cases/milan_lukic_sredoje_lukic/acjug/en/121204_jud gement.pdf.

16. Stakić Appeal Judgement. URL: http://www.icty.org/x/cases/stakic/ acjug/en/sta-aj060322e.pdf.

17. Stanišić and Župljanin Trial Judgement. URL: http://www.icty.org/x/cases/zupljanin_stanisicm/tjug/en/130327-1.pdf.

18. Popović et al. Appeal Judgement. URL: http://www.icty.org/x/cases/popovic/acjug/en/150130 judgement.pdf.

19. Kvočka et al. Appeal Judgement. URL: http://www.icty.org/x/cases/kvocka/acjug/en/kvo-aj050228e.pdf.

20. Tolimir Appeal Judgement. URL: http://www.icty.org/x/cases/ tolimir/acjug/en/150408 judgement.pdf .

21. Martić Trial Judgement. URL: http://www.icty.org/x/cases/martic/ tjug/en/070612.pdf.

22. Stakić Trial Judgement. URL: http://www.icty.org/x/cases/stakic/ tjug/en/stak-tj030731e.pdf.

23. Brđanin Trial Judgement. URL: http://www.icty.org/x/cases/ brdanin/tjug/en/brd-tj040901e.pdf. 
24. Blagojević and Jokić Trial Judgement. URL: http://www.icty.org/x/cases/blagojevic jokic/tjug/en/bla-050117e.pdf.

25. Krajišnik Trial Judgement. URL: http://www.icty.org/x/cases/ krajisnik/tjug/en/kra-jud060927e.pdf.

26. Stanišić and Župljanin Appeal Judgement. URL: http://www.icty.org/x/cases/zupljanin_stanisicm/acjug/en/160630.pdf.

27. Дайджест МКТЮ №160. URL: http://www.icty.org/x/file/About/ ReportsandPublications/ICTYDigest/2017/icty_digest_160_en.pdf.

Гринчак А. A.

\section{ПРИЗНАКИ ПРЕСТУПЛЕНИЙ ПРОТИВ ЧЕЛОВЕЧНОСТИ ПО УСТАВУ МЕЖДУНАРОДНОГО УГОЛОВНОГО ТРИБУНАЛА ПО БЫВШЕЙ ЮГОСЛАВИИ}

Статья посвящена анализу признаков преступлений против человечности по уставу Международного уголовного трибунала по бывщей Югославии и его практики в отношении этих преступлений. Раскрыто определение преступлений против человечности как таких, которые совершаются «в ходе вооруженного конфликта, международного или внутреннего характера, и направлены против любого гражданского населения». Особое внимание уделено характерным признакам преступлений против человечности, а именно: направленность против гражданского населения, организованность и систематичность, масштабность действий.

Ключевые слова: преступления против человечности, Международный уголовный трибунал по бывшей Югославии.

Grynchak A. A.

\section{MAIN CHARACTERISTICS OF CRIMES AGAINST HUMANITY UNDER THE STATUTE OF INTERNATIONAL CRIMINAL TRIBUNAL FOR THE FORMER YUGOSLAVIA}

The report is devoted to the analysis of main characteristics of crimes against humanity under the statute of the International Criminal Tribunal for the former Yugoslavia and its practice about these crimes. The definition of crimes against humanity is described as "when committed in armed conflict, whether international or internal in character, and directed against any civilian population». Special attention is paid to the characteristics of crimes against humanity, namely: orientation against the civilian population, organization and systematic, massiveness of actions.

Certainly, the significant influence of the ICTY on the development of International Humanitarian and Criminal Law and International Criminal Tribunal must be emphasized. The court practice has filled the legal gaps in certain international crimes and crimes against humanity in particular, and has become a significant factor in the elaboration of the statute of the International Criminal Court, the Special Court for Sierra Leone and other judicial institutions. The ICTC has proven that International Criminal Tribunal is effective and transparent. The definition of crimes 
against humanity is disclosed in the following international instruments, with consideration of all the achievements and achievements of the ICTY.

Key words: crimes against humanity, International Criminal Tribunal for the former Yugoslavia, an armed conflict, Criminal Law, the Special Court for Sierra Leone.

УДК 4(477):342.5

Пекарчук В. М., доктор історичних наук, доцент, професор кафедри теорії та історії держави і права, конституційного права, Академія Державної пенітенціарної служби, м.Чернігів

\section{СТАНОВЛЕННЯ ЗАКОНОДАВЧОЇ ВЛАДИ В УКРАЇНІ: ТЕНДЕНЦІї 90-Х РР. ХХ СТ.}

На основі всебічного аналізу різнопланових джерел досліджено особливості правового статусу та форм діяльності Верховної Ради України, ї̈ взаємодія з іншими органами центральної влади в умовах незалежності. У статті зазначено, щзо в першій половині 90-х років XX cm., особливо до прийняття Конституиії 1996 р., повноваження Верховної Ради України почали звужуватися, оскільки відбувався поступовий перехід від парламентської моделі до президентсько-парламентської республіки.

Ключові слова: парламент, президент, президентсько-парламентська республіка, Конституція України, Конституційний договір.

Постановка проблеми. Події останньої чверті століття, з відомих причин, переконливо доводять, що проблематика державного будівництва не тільки не втратила актуальності, а й потребує все більшої уваги з боку і науковців, і політикуму, і держави. Становлення парламентаризму в Україні є тривалим і складним процесом, що відбиває всі труднощі структуризації українського суспільства, недосконалість державного й партійного будівництва, неналежний рівень політичної і правової культури вітчизняного політикуму. На цей час у країні починає набирати обертів кампанія 3 виборів уже дев'ятого складу парламенту. Однак немає підстав говорити про усталеність засад і відповідність практик вітчизняного парламентаризму демократичним стандартам, про стабільне законодавче забезпечення парламентських виборів і конституційне - статусу, повноважень і функцій Верховної Ради України. Кожна виборча кампанія відбувається за новим законом, що змінює не лише процедуру, а й систему виборів; змінюється також роль і місце вищого законодавчого органу в 